\title{
Need for Complementary Approach in Primary Parkinson's Disease: Future Healthcare Perspective
}

\section{Nair SD*}

Former Assistant Professor of Panchakarma, Parassinikkadavu Ayurveda Medical College, India

*Corresponding author: Dr. Sandeep D Nair, MD MSc FNR, Former Assistant Professor of Panchakarma at Parassinikkadavu Ayurveda Medical College (PAMC), Kannur, India, Email: s.nair@t-online.de

\section{Short Communication}

A compilation of varied presentation of symptoms of a Parkinson's patient is as follows:

"I am a patient with Parkinson syndrome. I am unable to perform my daily activities and I have tremor in my hands. When I wake up early morning, I am a stone, I cannot move a step, and I am unable to get up from my bed. Then my wife brings the tablets for me and I take it and wait for the tablet to start its work. Every day I feel like I must take birth repeatedly. I am fed up with this process, I am afraid of going to sleep and this fear brings disturbance in sleep too. My voice is hoarse my expressions are gone, I cannot express my emotions, I bet you cannot tell whether am happy or sad from my face. I do not have to go to toilet regularly because the stools do not want to come out and urine does not want to stop its flow, so I must wear napkins as a child. Whenever I want to walk, I am stiff and whenever I dreamt of sitting calm, I am hyperkinetic. I cannot say anything else due to decreased memory, sometimes I want to say something, but I cannot find the correct word."

There are different types of diseases that have the Parkinsonian symptoms hence the term Parkinson's patient seems to be a generalised one. Essential tremor to vascular Parkinsonism is collectively called Atypical Parkinson and Parkinson Plus syndrome includes Multiple System Atrophy, Progressive Supranuclear Palsy, Corticobasal degeneration, Wilsons disease and Lewy body Dementia. In this short article, first I would like to analyse the available treatment approaches of Primary Parkinson's Disease. Main subtypes include Tremor dominant type (26-40\%), Akinetic rigid or Postural instability gait disorder (38-49\%) and mixed type.
Currently there is no cure for Parkinson's disease, but Physicians manage the symptoms by medication and therapies. This means there are no standard treatments for the disease - the treatment for each person with Parkinson's is based on symptoms. Treatments include medication and surgical therapy. The main drugs used to treat a Parkinson's disease are the dopamine substitutes. The dopamine precursor L-dopa, which is always held in a fixed combination with a so-called decarboxylase inhibitor such as benserazide or carbidopa. COMT inhibitor (catechol-0-methyl transferase inhibitor) and MAO inhibitors such as rasagiline B also act in isolation of L-dopa. Dopamine agonists are substances that mimic the physical dopamine in the brain. A dopamine agonist is a compound that activates dopamine receptors in the absence of that receptor's physiological ligand, the neurotransmitter dopamine. There are 10 different dopamine agonists. Eight of these dopamine agonists are absorbed through the gastrointestinal tract. A single dopamine agonist, Apomorphine is, a drug for injection subcutaneously with a ballpoint pen-like syringe or a pump (similar to that of Insulin pumps) Another dopamine agonist, rotigotine which is regarded as the Parkinson's patch (Plaster), because it is the only Parkinson's medication that is absorbed through the skin (Transdermal Drug delivery). In addition, several drugs for specific non-motor problems of Parkinson's disease are given namely antipsychotic clozapine for pharmacogenic psychosis and the cholinesterase inhibitor rivastigmine for associated dementia in Parkinson's disease.

"I know my husband is not back. He has left our children and me. His partners are constantly changing. He says he feels better than ever. This hurts so much! He lied and cheated. However, after I had logged him in a Parkinson Clinic, with 
new drugs, the man came slowly back to the fore. Is it really side effects of Parkinson drugs?

There is indeed a problem called Hyperactive sexuality associated with Parkinson's medication. The libido of the person concerned is greatly increased. Furthermore, these include pathological gambling, impulsive eating, and shopping. All these side effects are strongly associated with the dopamine agonist therapy like pramipexole. Even under low dosage side effects of this kind may occur. Levodopa can cause the following side effects like abnormal thinking ( holding false beliefs that cannot be changed by fact), agitation, anxiety, confusion, difficulty in swallowing, dizziness, excessive watering of mouth, false sense of wellbeing, hallucinations (optical, auditory), nausea or vomiting, numbness, Hyperkinesia( including the face, tongue, arms, hands, head, and upper body) and unusual tiredness or weakness.

\section{Prayogah}

Shamayedyadhimekam Yoanyamudeerayeth I

\section{$>$ Na asau Vishudhah \\ - Shudhasthu shamayedyo na Kopayeth II A.H Su 13 $-16$}

That Treatment which cures one symptom and gives rise to another is not a Pure or appropriate treatment. Pure treatment is that which cures the disease and does not give rise to another. Therefore, as an Ayurveda Physician our aim should be to provide Shudha Chikitsa for the Patients. The Modern system of Medicine now realises the importance of the wisdom of Ayurveda; hence the integration of medical systems is gaining popularity throughout the world. Complementary medicine research can be carried by providing combination of medicines and treatment methods from two different medical system or by integrating the treatment principle of one system into another or by using one system as an associated treatment along with the main stream approach or by a combination of all these. Any way the focus is the Patient. Rogers and Sheaff remind us that the "justification for integrated delivery systems is to meet patients' needs rather than providers'". Organizations that fail to place the patient at the centre of their integration efforts are unlikely to succeed .Integrated health systems should be easy for patients to navigate and it may be challenge for integrated systems to retain a patient focus.

\section{$>$ "Integration of two Systems is Creation of a New System"}

Protecting the patient from the etiological factor is the first step for treatment. Nevertheless, how this is possible in diseases like Primary Parkinsons, whose aetiology is still unknown. Accummulation of alpha-synuclei protein called as Lewi bodies in Substatia nigra causes the decreased production of dopamine transmitter leading to derangement in the motor pathway in turn causing movement disorder. Professor Braak's staging of pathology reveals that the accumulation starts form Olfactory bulb, Medulla oblongata and pontine tegementum. In this, premotor phase patients have Hyposmia, Constipation, and Depression and orthostatic dysregulation. However, the etiological factors that cause this accumulation of Lewi bodies is still unknown. However, Ayurveda has elaborately discussed about three main causes of disease, Asatmendriyartha samyoga, Pranjaparadha and Parinama. All the etiological factors of different diseases whether it is Nija or Aganthu vyadhi, Kshudra or Maha vyadhi, Sadhya or Asadhya vyadhi can be included in the above Trividha Roga Karanas. Hence, whatever may be the causes of Primary Parkinsons disease; it should fall under the Trividha karanas. Therefore, the first and prime step is to prevent the Atiyoga and Mithya yoga of Indriyas and Indriyarthas there by blocking the further entry of etiological factors into body. Avoid all the Dosha prakopa nidanas; attain the measures to maintain Dhi Dhrithi and Smrithi and protecting the individual from adverse effects of weather and ageing. The first step would be to regulate the diet and activities by advising Pathya Ahara Vihara, Dinacharya, Ritucharya, Yoga and Dhyana. During the treatment days as Inpatient, all these charyas can be introduced to the patient and regularly practiced thereafter when the patient is discharged from the Hospital.

\section{$>$ Sankshepathaha \\ - Kriyayogo Nidanaparivarjanam II Sushrutha Samhitha}

Analysing the signs and symptoms of Primary Parkinsons disease, we can find the various lakshanas similar to those described in Kampavata, Kaphavrutha Vyana and Kaphavrutha Udana like Karapada Tale kampa, Dehabhramana, Nidrabhanga, Kshinamati, Gati sanga, Guruta anga, Cheshta stambha, Vakgraha, Dourbalya and Mandagni. The next step would be to adopt the Chikitsa for the above Samprapthi. Trividha pareeksha, Ashtasthana Pareeksha and Dashavidha Pareeksha helps to infer the Samprapthi ghatakas like Dosha, Dushya, Srothas, Agni and Ama. To carry on with the Samprathi vighatana Chikitsa, it is very important to analyse the avastha of the above Samprapthi ghatakas. The success of Chikitsa are analysed by the intactness of Samprapthighatakas along with the decreased lakshanas. Trividha pareeksha is to analyse the case history to figure out the Roopa, Poorvarupas, Nidana, Upashaya Anupashaya and Samprapthi. Ashtasthana Pareeksha is a regular analysis tool for the dosha avastha of the patient during the IP treatment. Dashavidha Pareeksha is for determination of Chikitsa suthra (Treatment and Medicines). Kaphavarana Chikitsa is done followed by Vatahara chikitsa. Amahara, Agnivardhaka and Brihmana Medicines are given regularly, Repeated 
Snehaswedana after sufficient Ruksha Treatments are done and Mridu Anulomanas, Vasthis and Nasya are conducted. Managing the Complications of the disease and Side effects of medicine is also a big challenge in Conventional medicine. Ayurveda plays a role of Anubandha chikitsa by managing these Side effects and Upadravas.

\section{$>$ Thesham Shodhana Shamana Ahara Achara: Samyakprayuktha Nigrahahethava \\ - Charaka Samhitha Vimana 8}

It is not so easy to say which treatment helped more. However, it is evident that by introducing the Ayurveda principles and treatmentmethods along with the conventional method gives more stability in Primary Parkinsons Disease. Very few but increasing number of Patients with recent diagnosis treated only with Ayurveda medicines; are stable without aggravation in symptoms and maintaining an improved lifestyle along with Ayurvedoktha Pathayahara vihara, Dinacharya and Ritucharya. Despite the multitude of above instructions, patients do not feel pressured by their physician. Instead, they value the opportunity to cope actively with their disease by contributing to its cure or the alleviation of symptoms. The integrative approach opens large options for the patient. As I am working in such a department where the Neurologists and Ayurveda doctors go hand in hand to provide the optimum care for the patients, I can feel the positive wave among the patients towards complementary system that satisfy their health care needs. Our Chief, Professor Dr Przuntek, an eminent Neurologist, and former Professor in Neuromedicine Bochum Ruhr University say.

"Ayurveda is the result of continuous development of science-based health system. Here the principles, theories and guidelines of a healthy life and treatment for diseases are summarized. Health is a dynamic integration of environment, body, mind, and spirit. Ayurveda attaches great importance to the preservation and promotion of health. Prevention begins at birth."

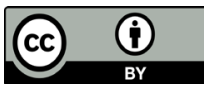

